\title{
The Imprisonment of Occupy Student Leaders
}

Public Reactions and Debates over Hong Kong's Judicial Independence

Ting-Fai Yu

\section{(2) OpenEdition}

\section{Journals}

Electronic version

URL: http://journals.openedition.org/chinaperspectives/7490

ISSN: 1996-4617

\section{Publisher}

Centre d'étude français sur la Chine contemporaine

\section{Printed version}

Date of publication: 1 December 2017

Number of pages: 59-62

ISSN: 2070-3449

\section{Electronic reference}

Ting-Fai Yu, «The Imprisonment of Occupy Student Leaders », China Perspectives [Online], 2017/4 |

2017, Online since 01 December 2017, connection on 28 October 2019. URL : http://

journals.openedition.org/chinaperspectives/7490 


\title{
The Imprisonment of Occupy
}

\section{Student Leaders}

\author{
Public Reactions and Debates over Hong Kong's Judicial Independence
}

TING-FAI YU

\section{Introduction}

$\mathrm{O}$ n 17 August 2017, three prominent Occupy leaders, Alex Chow Yong-kang, Nathan Law Kwun-chung, and Joshua Wong Chi-fung, were found guilty of unlawful assembly and handed prison sentences of six to eight months for storming Civic Square (the government headquarters) on 26 September 2014, setting off a series of sit-in protests over the next 79 days that configured into the Umbrella Movement (see, e.g. Kwok and Chan 2017; Ng 2016). In an earlier trial at the Eastern Magistrates' Court in August 2016, Magistrate June Cheung Tin-ngan, who considered the offense different from ordinary criminal cases, sentenced Law and Wong to community service orders while giving Chow a suspended jail sentence so he could commence his study overseas. (1) Deeming the lower court's judgment too lenient, the Department of Justice applied for judicial review in hopes of pushing for harsher punishments. On the basis that the initial trial "did not consider that the sentence should have a deterrent element, while giving disproportionate weight to factors such as personal circumstances and the respondents' motives," (2) the Court of Appeal justified its intervention by arguing that the magistrate disregarded the seriousness of the case and erred in granting community service orders.

Two days before the jailing of the Occupy leaders, 13 land rights activists, who were similarly convicted of unlawful assembly and initially sentenced to community service orders for protesting against the funding plan for the Northeast New Territories development proposal in 2014, were jailed for eight to 13 months by the Court of Appeal on 15 August 2017. (3) Following the latest run of public backlash such as the disqualification of four prodemocracy legislators (Lau Siu-lai, Nathan Law Kwun-chung, Leung Kwokhung, and Yiu Chung-yim) in July 2017, the jailing of the Occupy leaders and land rights activists has attracted immense local and international attention as well as triggering unprecedented debate over Hong Kong's judicial independence among the general public and in various sectors of society. To uncover the event's impacts on Hong Kong society, this article will present a concise overview of public reactions to the rulings, the debates over Hong Kong's judicial independence, as well as the international support for the Occupy leaders.

\section{Public reactions to the rulings}

On the Sunday after the two rulings, 20 August 2017, 22,000 people (by police estimates) marched in the streets demanding the immediate release of the jailed activists. ${ }^{(4)}$ In what was by far the largest public demonstration since the Umbrella Movement in 2014, protesters described the Occupy trio and the 13 land rights activists as "political prisoners," and were convinced that the jailing was the result of Beijing's political influence and that "the activists were imprisoned to stop them from running for office during the next five years." (5) Soon after the protest, the civil society group Story Of the FronTiers (SOFT) was set up on social media to support the jailed activists, ${ }^{(6)}$ and the Imprisoned Activists Support Fund was established by activists, scholars, and politicians in early September to solicit financial support for them. ${ }^{(7)}$

A second protest attracting 4,300 attendees by police estimates $(40,000$ according to the organizers' estimation) in support of the Occupy trio took place on 1 October during the National Day holiday. While the first protest called for the immediate release of the activists, the second rally placed the emphasis on protesting against "authoritarianism" - translated into Chinese as weiquan (威權)(8)—and demanded the resignation of Rimsky Yuen Kwok-

1. Jasmine Siu, "No Jail for Occupy Leaders Joshua Wong and Nathan Law, with Law Still Clear for Legco Run," South China Morning Post, 15 August 2016, http://www.scmp.com/news/hongkong/law-crime/article/2004016/no-jail-occupy-leaders-joshua-wong-and-nathan-law-law-still (accessed on 12 October 2017).

2. Jasmine Siu, "Read the Hong Kong Court of Appeal's Ruling on Joshua Wong, Nathan Law and Alex Chow, Jailed for 2014 Protest," South China Morning Post, 19 August 2017, http://www.scmp.com/news/hong-kong/politics/article/2107474/read-hong-kong-court-appeals-ruling-joshua-wong-nathan-law (accessed on 12 October 2017).

3. Karen Cheung, "13 Activists Who Stormed Hong Kong Legislature Jailed Following Successful Appeal by Justice Dept.," Hong Kong Free Press, 15 August 2017, https://www.hongkongfp.com/ 2017/08/15/13-activists-stormed-hong-kong-legislature-jailed-following-successful-appeal-justice-dept/ (accessed on 12 October 2017).

4. Jeffie Lam, "Protesters Turn Out in Force against Jailing of Hong Kong activists," South China Morning Post, 20 August 2017, http://www.scmp.com/news/hong-kong/politics/article/2107529/former-hong-kong-bar-association-chief-says-jailing-three (accessed on 12 October 2017).

5. Tom Phillips, "Thousands March in Hong Kong for Release of Pro-democracy Leaders," The Guardian, 20 August 2017, https://www.theguardian.com/world/2017/aug/20/hong-kong-prodemocracy-march-alex-chow-nathan-law-joshua-wong (accessed on 12 October 2017).

6. Karen Cheung, "Imprisoned But Not Forgotten: New Group Seeks to Support Hong Kong's Jailed Democracy Activists," Hong Kong Free Press, 27 August 2017, https://www.hongkongfp.com/ 2017/08/27/jailed-not-forgotten-new-group-seeks-support-hong-kongs-jailed-democracy-activists/ (accessed on 12 October 2017).

7. Karen Cheung, "Activists, Academics and Politicians Establish Independent Fund to Provide Assistance to Jailed Protesters" Hong Kong Free Press, 4 September 2017 https://www.hong kongfp.com/2017/09/04/activists-academics-politicians-establish-independent-fund-provideassistance-jailed-protesters/ (accessed on 12 October 2017).

8. "Dahui chen si wanren shangjie fan weiquan ai gang lunxian." (Organizers claim that 40,000 people protested against authoritarianism, lamenting the fall of Hong Kong), Apply Daily, 2 October 2017, http://hk.apple.nextmedia.com/news/art/20171002/20170296 (accessed on 12 October 2017); "'Fan weiquan' youxing jingmin baoren shu cha babei cu yuan guo qiang xiatai dahui: si wanren canyu jing siqiansanbai." ("Against authoritarianism" protest, eight times difference in the estimated number of participants, demanding Rimsky Yuen Kwok-keung to step down, organizers: 40,000, police: 4,300), Ming Pao, 2 October 2017, https://news.mingpao.com/pns/dailynews/ web_tc/article/20171002/s00002/1506879697358 (accessed on 12 October 2017). 
keung, the SAR Secretary of Justice. (9) By calling the Hong Kong administration an "authoritarian government," (10) this shift in the protest focusfrom supporting the imprisoned subjects to criticizing the legal-political system-implies rising concern over the independence of the local judiciary and its legitimacy in protecting people's freedom. This is reflected in a South China Morning Post article quoting a 69-year-old protester as saying, "The rule of law has become a laughing stock." (11) While protesters have reached a consensus that the rule of law is in crisis, the local legal community has suggested otherwise.

\section{Debates over Hong Kong's judicial independence}

Honoured by the Basic Law for its "solemn commitment" (Davis 2015, p. 279) to Hong Kong residents, the city's judiciary, as legal scholar Fu Hualing $(2017$, p. 88) summarises, "is independent, competent, and effective; and the legal profession remains professional, independent, and wellawarded financially, socially, and politically" even after the 1997 handover. As a widely regarded colonial legacy, the rule of law-along with freedom and economic prosperity-is understood by Hong Kong people as one of the core values of Hong Kong society. Since the transfer of political sovereignty in 1997, the city's advanced legal infrastructure has often been framed as a source of pride for its residents to distinguish local governance and ways of life from those in mainland China. This difference between the "two systems" in the effectiveness of law in ensuring social wellbeing is indeed reflected in a number of objective measures. For example, in the latest Rule of Law Index published by the World Justice Project (WJP) in 2016, while Hong Kong is ranked $16^{\text {th }}$-positioned above many societies with relatively long traditions of democracy such as the United States $\left(18^{\text {th }}\right)$ and France $\left(21^{\text {st }}\right)$-China, by contrast, is ranked $80^{\text {th }}$ out of the 113 countries and jurisdictions surveyed. (12)

Given the significance of the rule of law-both administratively and symbolically-in maintaining the distinctiveness of Hong Kong society, questions concerning the city's legal autonomy were, rather unsurprisingly, the most heated and debated subject matter brought to light by the verdicts. In fact, soon after the court ruling, journalists and political commentators, both in Hong Kong and abroad, were quick to condemn the Department of Justice's application for review and regarded the sentences as the result of Beijing's political influence on the local judiciary. ${ }^{(13)}$ For example, calling the jailing "a watershed in Hong Kong's modern history" and the trio the city's "first political prisoners," (14) the New York Times cautioned that the ruling jeopardized Hong Kong's status as a judicially independent society under the constitutional principle of "one country, two systems," which entitles its citizens a high degree of freedom and autonomy.

While major media outlets were quick to conclude that the ruling was indicative of Beijing's intervention into the Hong Kong legal system, this view was overwhelmingly criticized by local legal practitioners and public figures involved in the city's legal sector, including Winnie Tam Wan-chi, the former chairwoman of the Hong Kong Bar Association, and lan Grenville Cross, the former Director of Public Prosecutions of Hong Kong. ${ }^{(15)}$ On 18 August 2017, the Bar Association and the Law Society of Hong Kong, "In a rare show of unity, difficult to achieve on most issues," (16) issued a joint statement in support of the verdict, emphasizing that "the decisions by the Hong Kong Courts are made solely according to law upon applications by one party or the other." (17) The statement moreover pointed out the danger that "unfounded comments that judicial decisions were made or influenced by political considerations originating outside Hong Kong are unjustified and damaging to our legal system, and to Hong Kong as a whole." (18)

Publicly known as an outspoken barrister who was critical of the Chinese government's decision for a possible interpretation of the Basic Law as a solution to the oath-taking controversy in 2016, (19) Tam, who has taken a firm stance in defence of the Hong Kong legal system, commented that there appeared to be no such indication of the Chinese government's interference in the court's decision (20) and reassured the public that the Court of Appeal has given a reasonable punishment for the charge of unlawful assembly. (21) Calling the public to respect the judiciary, she suggested that the international media-namely, the Wall Street Journal, the New York Times, and the Guardian (22)_likely did not study Judge Wally Yeung Chun-kuen's judgment before criticising the ruling as an act of political prosecution. ${ }^{(23)}$

9. Karen Cheung, "In Pictures: Hongkongers Rally against 'Authoritarian Gov't' on China National Day; Demand Justice Sec. Step Down," Hong Kong Free Press, 1 October 2017, https://www.hongkongfp.com/2017/10/01/pictures-hongkongers-rally-authoritarian-govt-chinanational-day-demand-justice-sec-step/ (accessed on 12 October 2017).

10. Ibid.

11. Phila Siu and Ng Kan-chung, "National Day Protest in Hong Kong Draws 40,000 to Streets, Organisers Claim," South China Morning Post, 1 October 2017, http://www.scmp.com/news/hongkong/politics/article/2113583/national-day-protest-hong-kong-draws-40000-streets (accessed on 15 October 2017).

12. World Justice Project, Rule of Law Index, 2016, https://worldjusticeproject.org/sites/default/files/ documents/RoLI_Final-Digital_0.pdf (accessed on 12 October 2017).

13. The Editorial Board, "Three Young Voices Versus a Superpower," The New York Times, 15 August 2017, https://www.nytimes.com/2017/08/15/opinion/hong-kong-activists-prisoners-china.html? rref=collection\%2Fsectioncollection\%2Fopinion-editorials\&action=click\&contentCollection=editorials\&region=stream \& module=stream_unit\&version=latest\&contentPlacement=85\&pgtype=sectionfront (accessed on 12 October 2017); Natasha Khan, "Hong Kong Protest Leader Joshua Wong Sentenced to Six Months in Jail," The Wall Street Journal, 17 August 2017, https://www.wsj.com/articles/hong-kong-protest-leader-joshua-wong-sentenced-to-six-monthsin-jail-1502958935 (accessed on 12 October 2017); Kent Ewing, "Hong Kong Should Protect Its Core Values, As the Communist Party's Only Claim to Legitimacy is Destined to Fade," Hong Kong Free Press, 4 September 2017, https://www.hongkongfp.com/2017/09/04/hong-kong-protectcore-values-communist-partys-claim-legitimacy-destined-fade/ (accessed on 12 October 2017).

14. The Editorial Board, "Three Young Voices Versus a Superpower," The New York Times, 15 August 2017, https://www.nytimes.com/2017/08/15/opinion/hong-kong-activists-prisoners-china.html ?rref=collection\%2Fsectioncollection\%2Fopinion-editorials\&action=click\&contentCollection =editorials\&region=stream\&module=stream_unit\&version=latest\&contentPlacement=85\&pgtype=sectionfront (accessed on 12 October 2017).

15. Phoebe Ng, "Justice Figure Defends Jailings," The Standard, 4 September 2017, http://www.thestandard.com.hk/section-news.php?id=187041\&sid=4 (accessed on 12 October 2017).

16. Suzanne Pepper, "Hong Kong's First Political Prisoners? A Stormy Fortnight for the SAR's Core Values," Hong Kong Free Press, 27 August 2017, https://www.hongkongfp.com/2017/08/27/hongkongs-first-political-prisoners-stormy-fortnight-sars-core-values/ (accessed on 15 October 2017).

17. The Hong Kong Bar Association and The Law Society of Hong Kong, "Joint Statement of The Hong Kong Bar Association and The Law Society of Hong Kong in Response to Criticisms of Judicial Independence in Hong Kong," 18 August 2017.

18. Ibid.

19. Ellie Ng, "Hong Kong Lawyers to Hold Silent March over Beijing's Decision to Intervene in LegCo Oath Row," Hong Kong Free Press, 4 November 2016, https://www.hongkongfp.com/2016/11/04/ hong-kong-lawyers-hold-silent-march-beijings-decision-intervene-legco-oath-row/ (accessed on 12 October 2017).

20. Ibid.

21. "Shuang xue san zi beiqiu lin ding guo tan yun zhi cheng caijue zhi shangsuting liju chongfen bu rentong shi zhengzhipohai." (Jailing of the three Occupy leaders, Paul Lam Ting-kwok and Winnie Tam Wan-chi support and do not agree the Court of Appeal's ruling is an act of political prosecution), Apple Daily, 27 August 2017, https://hk.apple.nextmedia.com/news/art/20170827/ 20133835 (accessed on 12 October 2017).

22. "Tan yun zhi: bujue zhongyang xiang fating shiya wei shi fa yingxiang gang falu wending." (Winnie Tam Wan-chi: no indication showing Chinese government interfered the court's ruling, interpretation of the law might affect Hong Kong legal system's stability), Ming Pao, 2 September 2017, https://news.mingpao.com/ins/instantnews/web_tc/article/20170902/s00001/1504316479249 (accessed on 12 October 2017).

23. "Tan yun zhi: waiguomeiti pengji xianggang sifa "jiuchengjiu jiu" wu yanjiu fating pan ci bengang falu jie bixu fanji." (Winnie Tam Wan-chi: 99\% of the foreign media who attacked Hong Kong's rule of law did not study the judgment, it is the Hong Kong legal sector's responsibility to react), Stand News, 2 September 2017, https://www.thestandnews.com/politics/譚允芝-外國媒體抨擊 香港司法-九成九九-無看法庭判詞-本港法律界必須反擊/ (accessed on 12 October 2017). 
Although the local legal sector has convincingly argued against the unground attacks and warned that the accusations' lack of evidence could undermine the city's rule of law, ${ }^{(24)}$ their efforts did not seem to appease civil society, which remained highly vocal for the trio even weeks after the court ruling. ${ }^{(25)}$ As the Hong Kong-based journalist Suzanne Pepper succinctly pointed out, "The lawyers' joint advisory [...] seems to have forgotten another of their liberal principles, namely, that credibility and legitimacy is [sic] as much about public perceptions as the institutions and procedures themselves." (26) She wrote, "[s]o that when large numbers of people do not see a decision as being fair and just, [...] then maybe something is not right with the judgement and public skepticism should be encouraged rather than shut down." (27) Indeed, regardless of whether there were any "outside influences" on the Court of Appeal's decision, the public reaction to the episode nevertheless reflects Hongkongers' increasing distrust of the local and Chinese governments, as well as the local legal community's declining moral authority to secure people's confidence in the "one country, two systems" framework.

\section{International support for the Occupy leaders}

While the Hong Kong legal practitioners considered imprisonment a reasonable consequence for leading a civil disobedience movement, the international media did not seem to agree. Moreover, given the immense exposure of the 2014 Umbrella Movement in international media and the growing scholarly interest in the global influence and circulation of Occupy movements (Bennett and Segerberg 2013; Steger and James 2013), it is rather unsurprising to learn that most critical voices have come from major journalistic outlets and academic communities outside the territory. The New York Times, for instance, is among the most outspoken critics to call for international attention to the "first prisoners of conscience" in Hong Kong, where "the Beijing-backed local government successfully pushed for harsher punishments." (28) Calling Wong, Law, and Chow "the most prominent leaders pushing an authoritarian China to honor its international and political commitments," Bari Weiss, the Times' staff editor and writer for the opinion section, compared them to political dissidents such as Andrei Sakharov, Václav Havel, and Aung San Suu Kyi, and called for the Nobel Peace Prize Committee (which opened its nominating season in September) to nominate the trio for next year's award. ${ }^{(29)}$

On the other side of the Atlantic, the London School of Economics and Political Sciences (LSE) issued a public statement on 14 September. ${ }^{\left({ }^{0}\right)}$ Expressing concern concerning Chow, who attended a LSE master's degree program while suspended from jail last year, (31) the School Management Committee stated that they "have contacted the UK Government and the Hong Kong authorities to understand his situation and seek reassurances over his wellbeing" and will ensure that Chow can "complete his studies at LSE as soon as he is able to." (32) On 15 September, 36 professors from worldrenowned institutions, including a number of prominent academics such as David Graeber, Saskia Sassen, and Richard Sennett, issued an open letter calling for the immediate release of the trio and urging "the governments of the Hong Kong Special Administrative Region and of the People's Republic of China to respect the rule of law and political rights in Hong Kong." (33)

Solidarity protests were also staged in London and Taipei, where local citizens sought to put international pressure on the Chinese and Hong Kong governments. On the day of the mass demonstration in Hong Kong on 20 August, around a hundred protesters gathered outside the Hong Kong Economic, Trade and Cultural Office in Taipei's Xinyi District in support of the jailed activists. ${ }^{(34)}$ On 23 August, around 10 people protested in front of the Foreign and Commonwealth Office in London, where Benedict Rogers, the Deputy Chairman of the Conservative Party Human Rights Commission, "read out a statement signed by 25 public figures, including parliamentarians, lawyers and civil society leaders from the UK, the US, Canada, Malaysia, Indonesia and Myanmar." (35) Chris Patten, the last British governor, who served Hong Kong from 1992 to 1997 and is now chancellor of the University of Oxford, criticized the incarceration of the Umbrella Movement activists at the Edinburgh Book Festival, where he told an audience that "their names will be remembered, long after nobody can remember who I was, and perhaps nobody can remember who President Xi Jinping was." (36) Despite the unprecedented level of public support by civil society leaders from around the world, their actual impact on Hong Kong's democratic development remains to be seen in the years to come.

\section{Conclusion}

Similar to other recent episodes of post-Umbrella public backlash, such as the disqualification of legislators, the proposal for enforcement of mainland law at the Guangzhou-Shenzhen-Hong Kong Express Rail Link

24. Frank Ching, "Jailing of Activists: Foreign Critics Undermine HK Rule of Law," EJ Insight 4, September 2017, http://www.ejinsight.com/20170904-jailing-of-activists-foreign-critics-undermine-hk-ruleof-law/ (accessed on 15 October 2017); Jeffie Lam, "'Ungrounded' Attacks on Hong Kong's Judiciary are a Threat to the City's Rule of Law, Say Legal Experts," South China Morning Post, 26 August 2017, http://www.scmp.com/news/hong-kong/politics/article/2108408/ungrounded-attacks-hong-kongs-judiciary-are-threat-citys (accessed on 15 October 2017).

25. Phila Siu and Ng Kan-chung, "National Day Protest in Hong Kong Draws 40,000 to Streets, Organisers Claim," South China Morning Post, 1 October 2017, http://www.scmp.com/news/hongkong/politics/article/2113583/national-day-protest-hong-kong-draws-40000-streets (accessed on 15 October 2017).

26. Suzanne Pepper, "Hong Kong's First Political Prisoners? A Stormy Fortnight for the SAR's Core Values," Hong Kong Free Press, 27 August 2017, https://www.hongkongfp.com/2017/08/27/hongkongs-first-political-prisoners-stormy-fortnight-sars-core-values/ (accessed on 15 October 2017).

27. Ibid.

28. Alan Wong, "Joshua Wong and 2 Others Jailed in Hong Kong Over Pro-Democracy Protest," The New York Times, 17 August 2017, https://www.nytimes.com/2017/08/17/world/asia/hong-kongjoshua-wong-jailed-umbrella-movement.html?mcubz=1 (accessed on 15 October 2017).

29. Bari Weiss, "A Nobel Prize for Hong Kong's Democrats," The New York Times, 17 August 2017, https://www.nytimes.com/2017/08/17/opinion/hong-kong-democrats-prisonnobel.html?mcubz=1 (accessed on 15 October 2017).

30. "Statement on Imprisoned Student Alex Chow," LSE Staff News, 14 September, 2017 http://londonschoolofeconomicscommunications.newsweaver.com/staffnewsletter/ycxwz3awz5unaju5b40 ot2? $\mathrm{a}=2 \& \mathrm{p}=1888141 \& \mathrm{t}=549429$ (accessed on 15 October 2017).

31. Ellie Ng, "Gov't Loses Challenge to Unlawful Assembly Sentences against Occupy Activists Nathan Law, Joshua Wong, Alex Chow," Hong Kong Free Press, 21 September 2016, https://www.hong kongfp.com/2016/09/21/govt-loses-challenge-to-unlawful-assembly-sentences-against-occupyactivists-nathan-law-joshua-wong-and-alex-chow/ (accessed on 12 October 2017).

32. "Statement on Imprisoned Student Alex Chow," LSE Staff News, 14 September, 2017 http://londonschoolofeconomicscommunications.newsweaver.com/staffnewsletter/ycxwz3awz5unaju5b40 ot $2 ? \mathrm{a}=2 \& \mathrm{p}=1888141 \& \mathrm{t}=549429$ (accessed on 15 October 2017).

33. Kris Cheng, "London School of Economics Pledges Support for Jailed Hong Kong Activist Alex Chow, as 36 Scholars Call for His Release," Hong Kong Free Press, 15 September 2017, https://www.hongkongfp.com/2017/09/15/london-school-economics-pledges-support-jailedhong-kong-activist-alex-chow-36-scholars-call-release/ (accessed on 15 October 2017).

34. "Shengyuan xianggang zhengzhifan bai ren jieji gang zhu tai banshichu." (Supporting the Hong Kong political prisoners, a hundred protesters gathered at the Hong Kong Economic, Trade and Cultural Office), Liberty Times Net, 20 August 2017, http://news.ltn.com.tw/news/politics/breakingnews/2169025 (accessed on 15 October 2017).

35. Jun Pang, "Supporters of Jailed Hong Kong Activists Stage Solidarity Protests in London and Taiwan," Hong Kong Free Press, 24 August 2017, https://www.hongkongfp.com/2017/08/24/supporters-jailed-hong-kong-activists-stage-solidarity-protests-london-taiwan/ (accessed on 15 October 2017).

36. Reuters Staff, "Jailed Hong Kong Democracy Leaders Should be Source of Pride, Says Patten," Reuters, 18 August 2017, https://www.reuters.com/article/us-hongkong-politics-patten/jailedhong-kong-democracy-leaders-should-be-source-of-pride-says-patten-idUSKCN1AYOYW (accessed on 15 October 2017). 
station, and the recent appointment of Chief Executive Carrie Lam despite strong opposition, ${ }^{(37)}$ the imprisonment of the Occupy activists has again generated public concern over whether the verdict will put an end to Hong Kong's legal autonomy and its people's struggle for universal suffrage. However, according to many scholars such as Meaghan Morris (2017, p. 22), living with "distinctively date-stamped experiences of waiting first for 'the Handover' after the Sino-British agreement (1984-1996) and now living through the long inter-regnum of 'one country, two systems' (19972046)," this pessimistic speculation over the city's future and the public anxiety it produces are actually nothing new. In a prison letter written on 22 August, Alex Chow was perhaps right to point out and remind his supporters that local concerns have often been realised in times of crisis: "The core value of Hong Kong society has always formed and developed in fragile circumstances (xianggang de hexin jiazhi, xianglai dou shi zai cuiruo dangzhong chengzhang 香港的核心價值, 向來都是在脆弱當中成長)." (38)

Echoing Chow's statement, the prominent cultural critic Ackbar Abbas (1992, pp. 3-4) has pointed out that Hong Kong as a unique cultural entity worthy of attention is a relatively new idea that emerged "only after Thatcher's visit to China, and even more so after Tiananmen." Arguing for the culture of Hong Kong as a space of disappearance "whose appearance is posited on the imminence of its disappearance" (Abbas 1997, p. 7), Abbas suggests, "The anticipated end of Hong Kong as people knew it was the beginning of a profound concern with its historical and cultural specificity" (Ibid.). Indeed, instead of passively witnessing the disappearance of the city's specificities since the 1997 Handover, there emerged an unprecedented level of local concern and a territory-based Hong Kong identity that exceed the discourses of official histories (British or Chinese) (Chen and Szeto 2015). One example is the high-profile development of heritage preservation movements since the demolition of the Star Ferry Pier in 2007 and the Queen's Pier in 2008 (Chen and Szeto 2015; Henderson 2008; Ku 2012). Thinking along the same line as this scholarly optimism, rather than speculating whether or when the distinctiveness of Hong Kong will vanish, it is perhaps more productive to examine the city's resilience by asking what other new cultural formations will be configured in, as well as revitalize, the current state of fragility.

\section{ITing-Fai Yu is a research assistant at CEFC (tingfai.88.hk@gmail.com).}

CEFC News Analysis is compiled from the CEFC's fortnightly selection of Press Highlights, available at www.cefc.com.hk.

37. Claudia Mo, "This Is the Beginning of the End of Hong Kong," The Guardian, 7 November 2016, https://www.theguardian.com/world/2016/nov/07/this-is-the-beginning-of-the-end-of-hongkong-china (accessed on 15 October 2017); Christine Wang, "Activists Risk 'the End of Hong Kong' If They Respond the Wrong Way to Beijing, Experts Say," CNBC, 29 June 2017, https://www.cnbc.com/2017/06/29/activists-risk-the-end-of-hong-kong-if-they-respond-thewrong-way-to-beijing-experts-say.html (accessed on 15 October 2017).

38. Alex Chow, "Yu zhong shu-huangyan siqi women xu you shuochu zhenxiang de yongqi" (Prison letter: lies are everywhere, we must have the courage to tell the truth), Inmedia, 2 September 2017, https://www.inmediahk.net/node/1051826 (accessed on 15 October 2017).

\section{REFERENCES}

ABBAS, Ackbar. 1992. "Introduction:The Last Emporium:Verse and Cultural Space." In Ackbar Abbas, Leung Ping-kwan, and Gordon T. Osing, City at the End of Time. Hong Kong: Twilight Books. 3-19.

ABBAS, Ackbar. 1997. Hong Kong: Culture and the Politics of Disappearance. Minneapolis: University of Minnesota Press.

BENNETT, W. Lance, and Alexandra SEGERBERG. 2013. The Logic of Connective Action: Digital Media and the Personalization of Contentious Politics. New York: Cambridge University Press.

CHEN, Yun-chung, and Mirana M. SZETO. 2015. "The Forgotten Road of Progressive Localism: New Preservation Movement in Hong Kong." Inter-Asia Cultural Studies 16(3): 436-453.

DAVIS, Michael C. 2015. "The Basic Law, Universal Suffrage and the Rule of Law in Hong Kong." Hastings International and Comparative Law Review. 28(2): 275-298.

FU, Hualing. 2017. "Political Protest in High-Income Societies: The Case of the Occupy Central Movement in Hong Kong." In Brian Christopher Jones (ed.), Law and Politics of the Taiwan Sunflower and Hong Kong Umbrella Movements. New York, Routledge. 83-99.
HENDERSON, Joan C. 2008. "Conserving Hong Kong's Heritage: The Case of Queen's Pier." International Journal of Heritage Studies 14(6): 540-554.

KU, Agnes Shuk-mei. 2012. "Remaking Places and Fashioning an Opposition Discourse: Struggle over the Star Ferry Pier and the Queen's Pier in Hong Kong." Environment and Planning D: Society and Space 30(5): 5-22.

KWOK, Chi, and Ngai Kwung CHAN. 2017. "Legitimacy and Forced Democratisation in Social Movements." China Perspectives 2017(3): 7-16.

MORRIS, Meaghan. 2017. "Hong Kong Liminal: Situation as Method." In Yiu Wai Chu (ed.), Hong Kong Culture and Society in the New Millennium: Hong Kong as Method. Singapore: Springer. 3-32.

NG, Jason Y. 2016. Umbrellas in Bloom: Hong Kong Occupy Movement Uncovered. Hong Kong: Blacksmith Book.

STECER, Manfred B., and Paul JAMES. 2013. "Levels of Subjective Globalization: Ideologies, Imaginaries, Ontologies." Perspectives on Global Development and Technology 12: 17-40. 